\title{
Investigation into Erosion induced Highway Structural Failure along Ifon-Benin Highway, Southwestern Nigeria
}

Olumuyiwa Olusola Falowo ( $\square$ oluwanifemi.adeboye@yahoo.com )

Department of Civil Engineering Technology, Faculty of Engineering Technology, Rufus Giwa Polytechnic Owo, Ondo State, Nigeria

Research

Keywords: subgrade, penetrative resistance, bearing capacity, geologic section, erosion, flooding, highway

Posted Date: March 5th, 2020

DOl: https://doi.org/10.21203/rs.3.rs-16191/v1

License: (1) This work is licensed under a Creative Commons Attribution 4.0 International License. Read Full License 


\section{Abstract}

Geotechnical investigation was carried out at two failed segments along Ifon-Benin Highway, with the aim of determining cause, nature, and extent of the road failure. Eight in-situ cone penetration tests was carried out to a depth of about $20 \mathrm{~m}$ with a lateral spacing of $20 \mathrm{~m}$. This was complemented by collection of eight soil samples at different depths within the failed segments and analyzed in the laboratory. The laboratory tests conducted were grain size analysis, Atterberg limit test, compaction test, California bearing ratio, undrained unconfined triaxial test. The failure that existed in both locations are around the embankment, shoulder/edge and wearing course of the highway, due to ingression of water into the subgrade since the earth (natural soil) embankment structure had been eroded by rain water. The laboratory geotechnical results revealed that all the parameters could not meet up with the federal ministry of works and housing specification of Nigeria, with plasticity index greater than $20 \%$, fines greater than $35 \%$, CBR values less than $80 \%$ minimum recommended, shear strength parameters; angle of friction and cohesion are less than minimum of $30^{\circ}$ and $50 \mathrm{kPa}$ respectively. The CPT revealed predominant sandy silt to clayey silt topsoil and clay substratum with an inferred compressive strength of $20-40 \mathrm{KN} / \mathrm{m}^{2}$. At both failed segments, the clayey substratum is seriously affected within the upper $6 \mathrm{~m}$. The ingression of water into these foundation structures was due to compromise of the design/construction engineer, since a bridge was supposed to be erected across these two locations. Hence the stream channels across the highway were blocked by the earth-fill embankment. Therefore during wet season, pool of water that supposed to flow across the road through bridge system, continue to dissolve the embankment, and consequently infiltrate into the subgrade. This makes the highway to settle largely under traffic load. In addition, incessant heavy flooding around the embankment/shoulder of the highway might have induced the failure since a bridge was supposed to have been constructed across the two failed segments. This flooded water might have infiltrated into the pavement structural material leading to looseness, and lesscohesion of the layers which invariably reduces subgrade support and weakens various pavement layers.

\section{Introduction}

Transport is a key infrastructure of a country. A country's economic status depends upon how well served the country is by its roads, railways, air ports, ports, pipelines and shipping (Oglesby and Garry 1978; Paul and Radnor 1976). The rate at which a country's economy grows is very closely linked to the rate at which the transport sector grows (Kadyali and Lal 2008). Transport minimizes the time for the movement of people and goods, thus transport gives utility to economic activities and facilitates quick economic development. Road transportation is an important element in the physical development of any society as it controls the direction and extent of development (Daramola et al. 2018). The attention of the researcher was drawn to a road failure along Ifon - Benin highway in southwestern Nigeria. The failure occurs at two spots on the highway in the same form. Many accidents occurred along the failed spots leading to loss of lives and properties, especially for road users who prefer driving in the night. Consequently the Edo and Ondo States governments sealed those spots and prohibited vehicular movement indiscriminately along failed portion respectively, and also by providing alternative roadway. This was to prevent further accidents and encroachment of any form in the trouble spots. In fact at first, the seal restrained the researcher from probing into causes of the failure, until the permission was sought for this investigation. This type of highway failure is very common on Nigeria roads most especially in the sedimentary environment where excessive flooding, weathering, and erosion constantly usually erode the soft foundation soil (Abynayaka 1977). The state of the two failed segments has made travelling along road very unpleasant, armed robbers and kidnappers/unscrupulous people have made them their abode where criminal and nefarious activities are rising daily. This has denied the area of its viable economic activities, with attendant pollution and environmental degradation.

The blame-game between several professionals and government at all levels has not contributed positively to this ugly menace in the transport sector. However it's true that most design engineer and construction engineer always compromise design calculations and or models due to cost consideration, unforeseen problematic terrain/site condition. Most of the roads that were initially designed to carry heavy duty vehicles/large axle load are compromised in standard on site, hence most Nigeria roads is increasingly becoming unsafe with spectacular growth of traffic on the roads. Even most of the road users are impatient as they all want to escape potholes, rutting, cracks, pitting on most of the failed portions of the highways at the same time, leading to dangerous overtaking/manoeuvres resulting in accident, loss of lives and properties.

Normally, a road consists of a number of layers, each of which has a particular function. In addition, the type of pavement structure depends on the nature and number of the vehicles it has to carry, their wheel loads and the period of time over which it has to last (Brown 1996; Akpokodje 1986). The wearing surface of a modern road consists either of "black-top" (i.e. bituminous bound aggregate) or a concrete slab, although a bituminous surfacing may overlie a concrete base. A concrete slab distributes the load that the road has to carry, whereas in a bituminous road, the load primarily is distributed by the base beneath. The base and sub-base below the wearing surface generally consist of granular material, although in heavy-duty roads, the base may be treated with cement (John and Gorden 1976). The subgrade refers to the soil immediately beneath the sub-base. However much the load is distributed by the layers above, the subgrade has 
to carry the load of the road structure plus that of the traffic. Consequently, the top of the subgrade may have to be strengthened by compaction or stabilization (Hartley 1974; Black and Lister 1978). The strength of the subgrade, however, does not remain the same throughout its life. Changes in its strength are brought about by changes in its moisture content, by repeated wheel loading, and in some parts of the world by frost action. Although the soil in the subgrade exists above the water table and beneath a sealed surface, this does not stop the ingress of water. As a consequence, partially saturated or saturated conditions can exist in the soil. Also, road pavements are constructed at a level where the subgrade is affected by wetting and drying, which may lead to swelling and shrinkage, respectively, if the subgrade consists of expansive clay (US Army Corps of Engineer 2004).

The embankment as important element of pavement structure must also have sufficient bearing capacity to prevent foundation failure and also be capable of preventing excess settlements due to the imposed load (NITRR 1987). It should be designed as to protect the subgrade from getting damaged due to capillary rise in groundwater, provide ready drainage of surface water, ensure the needed geometric design standards, possess stable slopes and must not undergo excessive settlement. Subgrade strength being a vital parameter in pavement design, an adequately designed and constructed embankment. It is interesting to know that most highways in Nigeria lack surface drainage (which deals with arrangements for quickly and effectively leading away the water that collects on the surface of pavements, shoulders, slopes of embankments and cuts and the land adjoining the highways). Degradation of many highway pavements are traceable to the surface water ingress through cracks and joints in the embankment and shoulder of the highway (Ozegin et al. 2011).

Studies of past road failures showed some major causes of pavement failure, varying from usage, poor design and construction problems, use of substandard material for road construction, bedrock depressions, and presence of undetected linear features, such as fractures and rock boundaries ((Momoh et al. 2008; Daramola et al. 2018); heavy traffic, poor maintenance culture; poor highway facilities such as drainages; poor workmanship and supervision; and non-compliance to local standard of practice. Also some failures have been attributed to inadequate knowledge of the geotechnical characteristics and geomorphology during design and construction phases. Also clayey subgrade and embankments when not treated or stabilized could be responsible road failures. The engineering behaviour of near surface sub-tropical and tropical soils and rocks is a function of the impact of their interaction with the road environment and the weathering processes (Sandy and Cole 1982). Such characteristics may be attributable to their composition, the nature of their pore fluids, their mineralogy or their fabric (Saunders and Fookes 1970). Therefore the focus of this research is to determine the cause of the failure of the highway, the extent of dissolution of the subgrade material and its approximate depth using in-situ and laboratory geotechnical methods. This methods have proved its effectiveness in foundation studies and road failure investigation (Lumne et al. 1997; Coerts 1996; Oyedele and Okoh 2011; Olorode et al. 2016). CPT soundings can be very effective in site characterization (Oyedele and Olorode 2010; Coker et al. 2013; Coker 2015; Ayolabi et al. 2012; Bell et al. 1990).

\section{Description of Study Area}

The studied highway cut across two States of Nigeria, namely Ondo State and Edo State in southwestern and south-south regions respectively (Fig. 1). Two major segments of the highway had failed sometimes in year 2016 (Figs. 2 and 3) without due rehabilitation/reconstruction. The first segment is located in Ifon (Ose Local Government) while the second segment is in Owan area of Edo State (Fig. 3). The study area is underlain by sedimentary Benin and Ewekoro Formation which has been described severally in Akujieze (2004), Akujieze and Oteze (2006). Drifts and soil-cover characterized the formation over lateritic reddish brown clayey sand capping highly porous friable white sands, pebbly sands and clay stringers with basal indurated ferruginous pebbly - coarse grained sandstone. The Benin Formation is poorly bedded and occasionally cross - bedded at greater depths (Ntom 2001; Omatsola and Adegoke 1981).

The investigated road fall within the coastal region of Nigeria and the elevation is of low lying with elevation of not more than $100 \mathrm{~m}$ above the sea level. The Nigeria coastal zone is within the tropical climate areas. The rainy season is April to November and dry season is in December to march. The area has an annual rainfall varies between 1,500 and 4,000mm (Ibe 1988). Temperature in the coastal area is modulated by the cloud cover and by the damp air. However, the mean monthly temperature vary between $24^{\circ} \mathrm{C}$ and $32^{\circ} \mathrm{C}$. Mangrove and rain forests characterize the vegetation of the study area. The study area is located within the Niger Delta basin which is a major geomorphic feature in the Nigeria coastal zone. The evolution of the modern Niger Delta started in the Early Tertiary with sediments being supplied by the Niger - Benue river system which over the years have built-up a large Delta. The Niger Delta complex of sedimentary formations deposited in a high-energy deltaic environment.

\section{Methodology}


After thorough reconnaissance and desk studies, the cone penetrometer test (CPT) using Dutch cone penetrometer and geotechnical laboratory analysis of soil samples underlying the highway at different depths were employed for the in-situ subsoil characterization. The failed segments were distinguish into segment 1 and 2, representing Ifon-Sobe and Owan-Uyere respectively. The cone penetrometer test is a means of ascertaining the resistance of the soil by continuous measurement of resistance to penetration of the cone tip and frictional resistance (Lumne et al. 1997; Coerts 1996). A cone at the end of a series of rods is pushed into the ground at a constant rate, and measurements are made of the resistance to the penetration of the cone. This is known as "cone resistance" , which is the total force $\left(Q_{c}\right)$ acting on the cone divided by the projected area () of the cone. The cone resistance is a direct indicator of the strength of the soil at a given depth. Cost, efficiency, speed, simplicity, reliability, and the ability to provide near continuous information on the soil properties with depth are the important reasons for the increasing popularity of CPT, particularly useful in soft clays and loose sands.

Cone Penetration test was performed at a total of ten points (eight and two on failed and stable segments respectively) along roadway (Fig. 4). The tests were carried out to a depth of about $20 \mathrm{~m}$ with a spacing of $20 \mathrm{~m}$. In order to constrain or control the interpretation of the test, a control stable segment was established at each segments outside the failed portions. The Dutch static penetration measures the resistance of penetration into soils using a $60^{\circ}$ steel cone with an area of $10.2 \mathrm{~cm}^{2}$. The layer sequences are interpreted from the variation of the values of the cone resistance with depth. The test is carried out by securing the winch frame to the ground by means of anchors. These anchors provided the necessary power to push the cone into the ground. The cone and the tube are pushed together into the ground for 20 to $25 \mathrm{~cm}$; the cone is pushed ahead of the tube for $3.5 \mathrm{~cm}$ at a uniform rate of about $2 \mathrm{~cm} / \mathrm{sec}$. The resistance to the penetration of the cone registered on the pressure gauge connected to the pressure capsule is recorded. The tube is then pushed down and the procedure described above repeated. From the series of recorded gauge readings, cone resistance and sleeve friction are plotted against depth. The graph generated was interpreted using Robertson's soil classification chart (1990) as shown in Fig. 5; and Das (2000) soil classification using cone resistance value shown in Table 1.

Eight bulk disturbed soil samples were collected into polythene bags from foundation soil materials in borrow pits along the roadsides adjacent to both the failed and stable segments through boring/trial pit using hand auger. The disturbed soil samples were collected at regular intervals of about $0.5 \mathrm{~m}$ to maximum depths of $3 \mathrm{~m}$ and $1 \mathrm{~m}$ at locations 1 and 2 respectively. All samples were examined, identified, classified roughly in the field and all data and information carefully recorded before the conduct of laboratory tests. The natural moisture content of each of the samples collected was determined immediately it was taken to the laboratory. The Natural Moisture Content (NMC) of the subsoil samples was determined in the laboratory within the period of 24 hours after collection. The rest of the soil samples were air dried by spreading them out on trays in a fairly warm room for four days. Large soil particles (clods) in the samples were broken with a wooden mallet. Care was taken not to crush the individual particles. All the methods employed in carrying out the geotechnical test complied with the procedures specified by the British Standard Institution BS 1377 (1990) methods of testing for civil engineering purposes.

The other tests carried out on air dried samples include grain Size analysis, specific gravity, consistency (Atterberg) limit, compaction test, undrained unconfined triaxial test and California Bearing Ratio. The change in weight of wet samples put in a can after oven drying were measured and recorded for moisture content test. Sieve analysis test was conducted on oven dried soil samples using set of sieves with mesh size ranging from 4.75 to $0.075 \mathrm{~mm}$ after the soil samples have been washed off using sieve with mesh size 0.425 and $0.063 \mathrm{~mm}$ which is believed to have removed the clay and silt content. The specific gravity of the soil samples were also determined by obtaining the ratio between the weight of each soil samples and the weight of equivalent volume of water. A Casangrande device, grooving tool and a spatula were used in the determination of the plastic and liquid limits of the moist soil samples. The moist samples were also placed in a shrinkage mould and oven dried in order to determine the linear shrinkage limits of the soil samples. Compaction test was done on each of the soil samples using modified protor method that employs $4.5 \mathrm{~kg}$ rammer and 5 layers with 25 blows per layer. $6 \mathrm{~kg}$ of air dried soil sample was measured and water content of the percentage optimum moisture content (OMC) obtained from the compaction test was added to each soil sample. The wet soil sample was compacted in five layers in the mould by giving each layer 55 uniformly distributed blows of $4.5 \mathrm{~kg}$ rammer. From this, California Bearing Ratio (CBR) test was carried out using the CBR compression machine. This was followed by air drying of all the samples for 1 week to obtain fairly constant moisture content. The soil tests carried out are Atterberg limits, grain size, specific gravity, natural moisture content, compaction, undrained unconfined triaxial test and California Bearing Ratio (CBR). The tests were done following British Standard Institution.

Table 1 Cone resistance value for a corresponding lithology of cohesive and granular soils. (Das 2000) 


\begin{tabular}{cccc}
\hline $\begin{array}{c}\text { Cone resistance value } \\
\left(\mathrm{kg} / \mathrm{cm}^{2}\right)\end{array}$ & Soil Type & $\begin{array}{c}\text { Inferred CU values } \\
\left(\mathrm{KN} / \mathrm{m}^{2}\right)\end{array}$ & $\begin{array}{c}\text { Cone resistance value } \\
\left(\mathrm{kg} / \mathrm{cm}^{2}\right)\end{array}$ \\
\hline $0-4$ & Very soft clay & 20 & $20-40$ \\
$0-6$ & Soft clay & $20-40$ & $40-120$ \\
$6-10$ & Firm clay & $40-75$ & $120-200$ \\
$10-20$ & Stiff clay & $75-100$ & Mery loose to loose \\
Above 20 & Very stiff clay to Hard & $100-150$ & Dense \\
& clay & And 150 & \\
\hline
\end{tabular}

\section{Results And Discussion}

The results of the geotechnical tests are presented in Tables 2 and 3 for location 1 and 2 respectively. At location 1, the natural moisture content (NMC) at the depth of 1 and $3 \mathrm{~m}$ ranges from 16.5 to $21.6 \%$ with an average of $19.3 \%$, and at location 2 , it ranges from 22 to 23.2 $\%$ with an average (avg.) of $22.9 \%$. The moisture content values are generally high, and may be due to the fact that, the samples were taken during raining season. The highest moisture content (with average $>20 \%$ ) was obtained at location 2 . The subsoil at depths 1 and 3 $\mathrm{m}$ have \% sand ranging from $14.2-53.0$ (avg. 31.4), \% fines is in between $47.0-85.8$ (avg. $68.6 \%$ ) at location 1. At location 2, the \% sand varies from 11.6 - 48.7 (avg. $30.15 \%$ ), \% fines ranges from $51.3-88.4$ (avg. $69.85 \%$ ). Therefore the subsoil within the upper $3 \mathrm{~m}$ is predominantly composed of sandy clay and sandy silt. All the soil samples generally contains \% fines higher than maximum of 35 recommended by Federal Ministry of Works and Housing of Nigeria (FMWH 1997) for a good subsoil material for civil engineering construction purpose. This correlates with the geology of the study area which is shale and sandstone. The specific gravity of soil increases with increasing compaction and decreasing porosity and compressibility. The specific gravity of the soil depends on the amount of sand and also depends on their mineral constituents and mode of formation of the soil. Therefore soils with high specific gravity have high load bearing pressure and strength. The specific gravity values in the study area range from 2.53 to 2.69 in location 1 and 2.66 to 2.67 in location 2. The obtained specific values fall short of minimum of 2.70 recommended for subgrade material by Federal Ministry of Works and Housing of Nigeria (FMWH 1997).

The liquid limit of the subsoil at the depth of 1 and $3 \mathrm{~m}$ at location 1 ranges from 54.1 to $65.8 \%$ and an average of $57.0 \%$. At location 2 , it varies from $55.2 \%$ to $56.3 \%$ (avg. of $55.8 \%$ ). High liquid limit values (above $50 \%$ ) are indicative of poor engineering and geological properties of subgrade soils (Jegede 1995). Liquid Limit of 50\% maximum (FMWH 1997) is recommended for sub-grade material for engineering constructions, and most of the soil samples fall within this value. Therefore the soil can be said to be incompetent to host foundation of any civil engineering structure. Generally, soils having high values of plastic limits are considered as poor foundation materials (Akintorinwa and Adeusi 2009). The plastic limit (PL) of the subsoil at location 1 and 2 ranges from 17.5 to $32.0 \%$ (avg. of 26.7 $\%$ ) and 25.1 to $28.3 \%$ (avg. of $26.7 \%$ ) respectively. The range of plasticity index obtained from location 1 and 2 are from 21.2 to $48.33 \%$ (avg. of $33.8 \%$ ) and 28.1 to $30.1 \%$ (avg. of $29.1 \%$ ) respectively. FMWH (1997) recommended plasticity index of $20 \%$ maximum for subgrade material for engineering constructions. The plasticity index of the soil samples fall out of the recommended range. According to Casangrande (1972) such soil can be said to be of high compressibility and plasticity and are therefore unsuitable for civil engineering construction. However the Casangrande plasticity chart (Casangrande 1947) in Fig. 6 shows Intermediate plasticity clay (Cl) and high plasticity clay $(\mathrm{CH})$ for most of the sampled soils, except S-4 taken from location 1 that shows intermediate plasticity silt (MI). This also corroborates the American Association of State Highway and Transportation Officials (1982) in Fig. 7 which rates the samples as fair to poor i.e. A-7/A-7-6 in location 1 and A-7 in location 2 (Fig. 8).

The MDD is the density of the soil at which any further increase in the moisture content leads to a reduction in the unit weight of the soil. The importance of compaction test is to improve the desirable load bearing capacity properties of a soil (Akintorinwa and Adeusi 2009). The degree of compaction is sensitive to moisture content. The best subsoil for foundation of engineering structures is that with high maximum dry density (MDD) at low OMC (Jegede, 1999). The maximum dry density for the soil samples varied between $1540 \mathrm{Kg} / \mathrm{m}^{3}$ and $1670 \mathrm{Kg} / \mathrm{m}^{3}$ (avg. $1610 \mathrm{Kg} / \mathrm{m}^{3}$ ) at location 1, and $1650-1720 \mathrm{Kg} / \mathrm{m}^{3}$ (avg. $\left.1685 \mathrm{Kg} / \mathrm{m}^{3}\right)$ while their optimum moisture content ranges between $21.2 \%-29.6 \%$ (avg. $25.3 \%$ ) and $21.9-23.1 \%$ (avg. $22.5 \%$ ) respectively. All the studied samples have MDD at high OMC. However samples exhibit higher MDD (greater than $1800 \mathrm{Kg} / \mathrm{m}^{3}$ ) and lower OMC (less than 20\%) are good as foundation soil for road and building structures. These values show that, the soils respond slowly to compaction.

California Bearing Ratio (CBR) is a test designed to assess the strength of soil especially for highway construction. The California Bearing Ratio (CBR) of the subsoil at location 1 and 2 ranges from 24 to $60 \%$ (avg. of $42.1 \%$ ) and 24.6 to $29.3 \%$ (avg. of $26.9 \%$ respectively. The standard specification of un-soaked CBR recommended according to FMWH (1997) is $80 \%$ minimum for subgrade materials for road construction in Nigeria. The CBR test results has shown that none of the soil samples tested has CBR value up to $80 \%$ minimum recommended for road construction. The shear strength parameters of the soil samples in terms of angle of friction and cohesion for location 1 and 2 vary between $17-26^{\circ}$ (avg. $22^{\circ}$ ) and $22-28^{\circ}$ (avg. $\left.25^{\circ}\right)$; and $19-32 \mathrm{kPa}$ (avg. $24.7 \mathrm{kPa}$ ) and $26-34 \mathrm{kPa}(\mathrm{avg} .30$ 
$\mathrm{kPa}$ ) respectively. Therefore soil showing higher shear strength parameters would be less susceptible to rupture or failure along any plane inside it. But all the soil samples have values less than minimum friction angle of $30^{\circ}$ and minimum cohesion of $50 \mathrm{kPa}$ specification.

The plots of cone resistance, sleeve resistance, and friction ratio against depth for stable segment and failed segments at location 1 are shown in Figs. 9 and 10. The control stable segment along this highway at location 1 comprises five major geologic units found at different depths; silty sand to sandy silt $(0-2 \mathrm{~m})$, clay/clay silt to silty clay $(2-6.5 \mathrm{~m})$, sand to silty sand $(6.5-9.0 \mathrm{~m})$, clay $(9-12.0 \mathrm{~m})$, silty sand to sandy silt $(12-16.5 \mathrm{~m})$ and sand $(16.5-18.75 \mathrm{~m})$. The cone resistance obtained from upper $3 \mathrm{~m}, 3-10 \mathrm{~m}$ and $10-18.25$ $\mathrm{m}$ vary from $10-48 \mathrm{~kg} / \mathrm{cm}^{2}$ (firm to stiff clay), $12-99 \mathrm{~kg} / \mathrm{cm}^{2}$, and $45-186 \mathrm{~kg} / \mathrm{cm}^{2}$, with corresponding sleeve resistance of $15-62$ $\mathrm{kg} / \mathrm{cm}^{2}, 62-114 \mathrm{~kg} / \mathrm{cm}^{2}$, and $114-248 \mathrm{~kg} / \mathrm{cm}^{2}$, while the friction ratio range from $0.62-5.33,0.86-5.23$, and $1.24-4.25$ respectively. It is observed that there is generally increase of cone resistance and sleeve resistance with depth except where there is an intercalation of clay. Consequently the erosion that leads to the failure of the road pavement and its shoulder didn't permeate into the stable segment. That is the reason for relatively high cone resistance and sleeve friction values obtained with the depth of $3-10 \mathrm{~m}$, which seems the problematic layer affected seriously by erosion. The CPT 2 is

Table 2 Summary of the Results of Subsoil Geotechnical tests for Location 1: Ifon - Sobe Failed Segment

\begin{tabular}{|c|c|c|c|c|c|c|c|c|c|c|c|c|c|c|c|}
\hline \multirow[b]{2}{*}{$\begin{array}{l}\text { Depth } \\
\text { (m) }\end{array}$} & \multirow[b]{2}{*}{$\begin{array}{l}\text { NMC } \\
(\%)\end{array}$} & \multicolumn{3}{|c|}{ Grain size Analysis } & \multirow[b]{2}{*}{$\begin{array}{l}\text { Specific } \\
\text { Gravity }\end{array}$} & \multicolumn{3}{|c|}{ Atterberg Limits } & \multicolumn{2}{|c|}{ Compaction } & \multirow[b]{2}{*}{$\begin{array}{c}\text { Un- } \\
\text { soaked } \\
\text { CBR } \\
(\%)\end{array}$} & \multicolumn{2}{|c|}{ UU Triaxial Test } & \multirow{2}{*}{$\begin{array}{l}\text { USCS } \\
\text { Group }\end{array}$} & \multirow{2}{*}{$\begin{array}{l}\text { AASHTO } \\
\text { Group }\end{array}$} \\
\hline & & $\begin{array}{c}\% \\
\text { Gravel }\end{array}$ & $\begin{array}{c}\% \\
\text { Sand }\end{array}$ & $\begin{array}{c}\% \\
\text { Fines }\end{array}$ & & $\begin{array}{c}\text { Liquid } \\
\text { limit } \\
(\%)\end{array}$ & $\begin{array}{c}\text { Plastic } \\
\text { limit } \\
(\%)\end{array}$ & $\begin{array}{c}\text { Plasticity } \\
\text { Index } \\
(\%)\end{array}$ & $\begin{array}{c}\mathrm{MDD} \\
\left(\mathrm{Kg} / \mathrm{cm}^{2}\right)\end{array}$ & $\begin{array}{c}\mathrm{OMC} \\
(\%)\end{array}$ & & $\begin{array}{c}\text { Angle } \\
\text { friction } \\
\left(^{\circ}\right)\end{array}$ & $\begin{array}{c}\text { Cohesion } \\
(\mathrm{kPa})\end{array}$ & & \\
\hline 0.5 & 16.5 & - & 22.0 & 78.0 & 2.67 & 65.80 & 17.47 & 48.33 & 1540 & 27.10 & 39.23 & 26 & 32 & $\mathrm{CH}$ & A-7-6 \\
\hline 1.0 & 18.3 & - & 53.0 & 47.0 & 2.69 & 52.14 & 22.69 & 29.45 & 1590 & 29.55 & 24.15 & 24 & 25 & CI & A-7 \\
\hline 1.5 & 20.3 & - & 14.2 & 85.8 & 2.60 & 52.77 & 22.58 & 30.19 & 1640 & 22.81 & 44.36 & 22 & 19 & CI & A-7-6 \\
\hline 2.0 & 20.4 & - & 23.0 & 77.0 & 2.53 & 53.16 & 32.00 & 21.16 & 1670 & 22.45 & 49.21 & 17 & 28 & ML & A-7 \\
\hline 2.5 & 19.5 & - & 43.7 & 56.3 & 2.57 & 54.71 & 18.62 & 36.09 & 1650 & 21.20 & 59.68 & 22 & 19 & CI & A-7-6 \\
\hline 3.0 & 21.6 & - & 27.9 & 72.1 & 2.55 & 59.68 & 24.29 & 35.39 & 1580 & 28.30 & 36.72 & 25 & 23 & CI & A-7-6 \\
\hline
\end{tabular}

Table 3 Summary of the Results of Subsoil Geotechnical tests for Location 2: Owan - Uyere Failed Segment

\begin{tabular}{|c|c|c|c|c|c|c|c|c|c|c|c|c|c|c|c|}
\hline \multirow[b]{2}{*}{$\begin{array}{l}\text { Depth } \\
\text { (m) }\end{array}$} & \multirow[b]{2}{*}{$\begin{array}{c}\text { NMC } \\
(\%)\end{array}$} & \multicolumn{3}{|c|}{ Grain size Analysis } & \multirow[b]{2}{*}{$\begin{array}{l}\text { Specific } \\
\text { Gravity }\end{array}$} & \multicolumn{3}{|c|}{ Atterberg Limits } & \multicolumn{2}{|c|}{ Compaction } & \multirow[b]{2}{*}{$\begin{array}{c}\text { Un- } \\
\text { soaked } \\
\text { CBR } \\
(\%)\end{array}$} & \multicolumn{2}{|c|}{ UU Triaxial Test } & \multirow{2}{*}{$\begin{array}{l}\text { USCS } \\
\text { Group }\end{array}$} & \multirow{2}{*}{$\begin{array}{c}\text { AASHTO } \\
\text { Group }\end{array}$} \\
\hline & & $\begin{array}{c}\% \\
\text { Gravel }\end{array}$ & $\begin{array}{c}\% \\
\text { Sand }\end{array}$ & $\begin{array}{c}\% \\
\text { Fines }\end{array}$ & & $\begin{array}{c}\text { Liquid } \\
\text { limit } \\
(\%)\end{array}$ & $\begin{array}{c}\text { Plastic } \\
\text { limit } \\
(\%)\end{array}$ & $\begin{array}{c}\text { Plasticity } \\
\text { Index } \\
(\%)\end{array}$ & $\begin{array}{c}\mathrm{MDD} \\
\left(\mathrm{Kg} / \mathrm{cm}^{2}\right)\end{array}$ & $\begin{array}{c}\mathrm{OMC} \\
(\%)\end{array}$ & & $\begin{array}{c}\text { Angle } \\
\text { friction } \\
\left(^{\circ}\right)\end{array}$ & $\begin{array}{c}\text { Cohesion } \\
(\mathrm{kPa})\end{array}$ & & \\
\hline 0.5 & 23.2 & - & 11.6 & 88.4 & 2.66 & 55.23 & 25.11 & 30.12 & 1650 & 23.12 & 24.59 & 22 & 26 & $\mathrm{CI}$ & A-7 \\
\hline 1.0 & 22.5 & - & 48.7 & 51.3 & 2.67 & 56.30 & 28.25 & 28.05 & 1720 & 21.85 & 29.31 & 28 & 34 & CI & A-7 \\
\hline
\end{tabular}

characterized by sandy silt to clayey silt/silty sand to sandy silt $(0-2 \mathrm{~m})$, clay $(2.25-11.5)$, clayey silt to silty clay $(11.5-13.25 \mathrm{~m})$, clay $(13.25-14.75 \mathrm{~m})$ and sandy silt to clayey silt $(14.75-18.25 \mathrm{~m})$. It is observed that the clay substratum under CPT 2 at depth $3-10 \mathrm{~m}$, is characterized by low cone resistance values ranging from $3-10 \mathrm{~kg} / \mathrm{cm} 2$ (soft clay, with inferred CU values ranging from $20-40 \mathrm{KN} / \mathrm{m}^{2}$ ) in comparison to the stable segment $\left(12-99 \mathrm{~kg} / \mathrm{cm}^{2}\right.$ : stiff to very stiff clay, with an inferred CU values varying from 100 to $\left.>150 \mathrm{KN} / \mathrm{m}^{2}\right)$, with corresponding sleeve resistance and friction ratio values of $22-74 \mathrm{~kg} / \mathrm{cm}^{2}$ and $4.23-5.20$ respectively. The cone resistance, sleeve resistance and friction ratio values obtained from upper $3 \mathrm{~m}$, and between $10-18.25 \mathrm{~m}$ vary from $3-33 \mathrm{~kg} / \mathrm{cm}^{2}$ and $12-101 \mathrm{~kg} / \mathrm{cm}^{2} ; 5$ $-36 \mathrm{~kg} / \mathrm{cm}^{2}$ and $52-190 \mathrm{~kg} / \mathrm{cm}^{2}$; and $0.51-5.12$ and $1.65-5.87$ respectively. In addition the upper $10 \mathrm{~m}$ has been seriously affected by the erosion resulting into low resistance observed on the graph (Fig. 9a). The geologic units under CPT 3 at location 1 consist of silty sand to sandy silt $(0-2 \mathrm{~m})$, clay $(2-10.5 \mathrm{~m})$, and silty sand to sandy silt/clay $(10.5-18.25 \mathrm{~m})$. The cone resistance obtained from upper $3 \mathrm{~m}$, $3-10 \mathrm{~m}$ and $10-18.25 \mathrm{~m}$ vary from $6-33 \mathrm{~kg} / \mathrm{cm}^{2}$ (firm clay/very loose sand), $4-13 \mathrm{~kg} / \mathrm{cm}^{2}$ (soft/firm clay), and $11-129 \mathrm{~kg} / \mathrm{cm}^{2}$ (stiff clay/medium-dense sand silt), with corresponding sleeve resistance of $7-36 \mathrm{~kg} / \mathrm{cm}^{2}, 18-59 \mathrm{~kg} / \mathrm{cm}^{2}$, and $52-195 \mathrm{~kg} / \mathrm{cm}^{2}$, while the friction ratio range from $0.40-4.52,4.25-5.98$, and $1.11-5.21$ respectively. Consequently the clayey soil under this CPT point is very soft/firm due to erosion, leading to high porosity and permeability resulting in high compressibility (reduction of soil strength and bearing capacity) and settlement under vehicular high axle load. CPT 4 is underlain by four geologic sequence, comprising clayey silt to silty sand $(0-1.75 \mathrm{~m})$, clay $(1.75-11.0 \mathrm{~m})$, sandy silt to clayey silt $(11.0-15.75 \mathrm{~m})$ and silty sand to sandy silt $(15.75-18.25 \mathrm{~m})$. The cone resistance values at upper $3 \mathrm{~m}, 3-10 \mathrm{~m}$, and $10-18.25 \mathrm{~m}$ vary from $4-15 \mathrm{~kg} / \mathrm{cm}^{2}, 3-15 \mathrm{~kg} / \mathrm{cm}^{2}$ (very soft - stiff clay with 
inferred CU varying from $20-80 \mathrm{KN} / \mathrm{m}^{2}$ ), and $12-102 \mathrm{~kg} / \mathrm{cm}^{2}$ (stiff clay/loose - medium dense sand silt), with sleeve friction values ranging from $15-32 \mathrm{~kg} / \mathrm{cm}^{2}, 14-62 \mathrm{~kg} / \mathrm{cm}^{2}$, and $68-188 \mathrm{~kg} / \mathrm{cm}^{2}$ respectively. The friction ratio obtained varies between $2.14-5.11$ (upper $3 \mathrm{~m}$ ), $4.02-5.69$ (3 -10 m depth), and 1.23 - 5.12 (10 - $18.25 \mathrm{~m}$ depth). The graph also depicts low resistance values to about 11.0 depth, after which it begins to increase. Consequently the clayey silt to silty sand and clay soil show less competence to carry imposed vehicular load. At CPT 5, the geologic units comprises four geologic units, which are sandy silt to clayey silt ( $0-2 \mathrm{~m})$, clay $(2.0-$ $7.25 \mathrm{~m})$, clayey silt to silty clay $(7.25-12 \mathrm{~m})$ and sand silt to clayey silt/silty sand to sandy silt $(12-18 \mathrm{~m})$. The cone resistance obtained from upper $3 \mathrm{~m}, 3-10 \mathrm{~m}$ and $10-18.25 \mathrm{~m}$ vary from $3-40 \mathrm{~kg} / \mathrm{cm}^{2}, 3-33 \mathrm{~kg} / \mathrm{cm}^{2}$ (very soft - very stiff clay, with inferred CU of 15 to $>20 \mathrm{KN} / \mathrm{m}^{2}$ ), and $9-151 \mathrm{~kg} / \mathrm{cm}^{2}$, with corresponding sleeve resistance of $14-25 \mathrm{~kg} / \mathrm{cm}^{2}, 17-56 \mathrm{~kg} / \mathrm{cm}^{2}$, and $48-201 \mathrm{~kg} / \mathrm{cm}^{2}$, while the friction ratio range from $0.45-5.13,1.54-5.36$, and $1.02-5.69$ respectively. Even though the upper $10 \mathrm{~m}$ of CPT 5 shows relatively increase values of cone resistance and sleeve friction than what is obtainable under CPT $2-4$, it's noted that the clayey substratum (to a depth of $9.25 \mathrm{~m}$ ) is still a challenge.

Therefore the failure along this segment could have been precipitated by incompetent soil material with considerable thickness of $8 \mathrm{~m}$ composing of clayey/silty material. The low penetrative resistance values (generally less than $10 \mathrm{~kg} / \mathrm{cm}^{2}$ and corresponding to soft clay with unconfined compressive strength of less than $75 \mathrm{KN} / \mathrm{m}^{2}$ ) and their looseness could be as a result of incessant erosion along this segment which have penetrated deeply to about $15 \mathrm{~m}$. Consequently considering weak geotechnical characteristics of the soil mass above $10 \mathrm{~m}$, there's need for it to be excavated during future rehabilitation/re-construction of the highway and fill with competent soil material like laterite or graded with sand/gravel. Although this may not guarantee the stability of this segment after rehabilitation/construction since an underground drainage system is required, and at the same time along the shoulders of the road.

At failed segment 2, the plots of cone resistance, sleeve resistance, and friction ratio against depth for stable segment CPT 6 and failed segments CPT 7 - 10 are shown in Figures 11 and 12. The control stable segment along this highway comprises five major geologic units found at different depths with clay alternation; clayey silt to silty clay $(0-4.25 \mathrm{~m})$, clay $(4.25-8.0 \mathrm{~m})$, clayey silt to silty clay/sand silt to clayey silt $(8-14.75 \mathrm{~m})$, clay $(14.75-17.5 \mathrm{~m})$, silty sand to sandy silt $(17.5-18.75 \mathrm{~m})$ and clay $(18.75-20 \mathrm{~m})$. The cone resistance values obtained from upper $3 \mathrm{~m}, 3-10 \mathrm{~m}$ and $10-18.25 \mathrm{~m}$ range from $3-25 \mathrm{~kg} / \mathrm{cm}^{2}$ (very soft clay/loose silt sand), $10-49 \mathrm{~kg} / \mathrm{cm}^{2}$, and $36-180 \mathrm{~kg} / \mathrm{cm}^{2}$, with corresponding sleeve resistance of $5-52 \mathrm{~kg} / \mathrm{cm}^{2}, 52-136 \mathrm{~kg} / \mathrm{cm}^{2}$, and $136-240 \mathrm{~kg} / \mathrm{cm}^{2}$, while the friction ratio range from $1.51-2.31,2.15-5.48$, and $1.25-5.36$ respectively. It is observed that there is generally increase of cone resistance and sleeve resistance with depth. Also clayey soil material intercalations generally have cone resistance values greater than $25 \mathrm{~kg} / \mathrm{cm}^{2}$ corresponding to very stiff/hard clay with inferred compressive strength of $100-150 \mathrm{KN} / \mathrm{m}^{2}$. In addition the topsoil composed of heterogeneous clayey silt to silty clay and sandy silt to clayey silt with relatively high qu and $\mathrm{Sr}$ in the range of $5-30 \mathrm{~kg} / \mathrm{cm}^{2}$ and $10-50$ $\mathrm{kg} / \mathrm{cm}^{2}$ could be responsible for stability of this segment.

The CPT 7 is characterized by sensitive soil/silty clay to clay $(0-2.75 \mathrm{~m})$, clay/sandy silt to clayey silt $(2.75-10.5)$, clayey silt to silty clay $(10.5-12.0 \mathrm{~m})$, silty sand to sandy silt/sandy silt to clayey silt/clayey silt to silty clay/ silty clay to clay $(12-16 \mathrm{~m})$ and clay $(18-$ $20 \mathrm{~m}$ ). The cone resistance, sleeve resistance and friction ratio ranges from $3-21 \mathrm{~kg} / \mathrm{cm}^{2}, 4-15 \mathrm{~kg} / \mathrm{cm}^{2}$, and $0.67-2.93$ for depth $0-3$ $\mathrm{m} ; 2-29 \mathrm{~kg} / \mathrm{cm}^{2}, 9-98 \mathrm{~kg} / \mathrm{cm}^{2}$, and $2.36-5.36$ for depth between $3-10 \mathrm{~m} ; 14-129 \mathrm{~kg} / \mathrm{cm}^{2}, 86-198 \mathrm{~kg} / \mathrm{cm}^{2}$, and $1.25-5.69$. The upper $6.5 \mathrm{~m}$ is characterized by low cone resistance values corresponding to inferred compressive strength of $20-40 \mathrm{KN} / \mathrm{m}^{2}$ signifying very soft to soft clayey/silty material. This could responsible for the failure at this point, since at this depth the stable segment is characterized by high cone resistance values ranging from $5-38 \mathrm{~kg} / \mathrm{cm}^{2}$, symptomatic of soft - hard clayey/silty soil material. Therefore the road constructed on incompetent soil mass which is geo-technically weak to withstand the traffic load along the highway. At CPT 8 , the geologic units consist of sensitive fine grained soil $(0-2.5 \mathrm{~m})$, clay $(2.5-11 \mathrm{~m})$, silty clay to clay/clayey silt to silty clay $(11-16 \mathrm{~m})$, clay $(16-18.75 \mathrm{~m})$, and sandy silt to clayey silt $(18.75-20 \mathrm{~m})$. The cone resistance obtained from upper $3 \mathrm{~m}, 3-10 \mathrm{~m}$ and $10-18.25$ $\mathrm{m}$ vary from $1-22 \mathrm{~kg} / \mathrm{cm}^{2}$ (soft - firm clay with inferred CU values of $20-150 \mathrm{KN} / \mathrm{m}^{2}$ ), $2-17 \mathrm{~kg} / \mathrm{cm}^{2}$ (very soft/firm clay), and $14-84$ $\mathrm{kg} / \mathrm{cm}^{2}$, with corresponding sleeve resistance of $3-15 \mathrm{~kg} / \mathrm{cm}^{2}, 9-88 \mathrm{~kg} / \mathrm{cm}^{2}$, and $74-205 \mathrm{~kg} / \mathrm{cm}^{2}$, while the friction ratio ranges from $0.55-5.21,2.33-5.55$, and $1.99-5.36$ respectively. Therefore the upper $18.75 \mathrm{~m}$ is clayey with very low cone resistance values, suggestive of soft-firm clay with unconfined compressive strength less than $75 \mathrm{KN} / \mathrm{m}^{3}$. CPT 9 is underlain by three major geologic sequence, comprising sandy silt to clayey silt $(0-2.75 \mathrm{~m})$, clay $(2.75-11.25 \mathrm{~m})$, clayey silt to silty clay $(11.75-15 \mathrm{~m})$ and clay $(15-20$ $\mathrm{m}$ ). The cone resistance values at upper $3 \mathrm{~m}, 3-10 \mathrm{~m}$, and $10-18.25 \mathrm{~m}$ vary from $5-19 \mathrm{~kg} / \mathrm{cm}^{2}, 2-17 \mathrm{~kg} / \mathrm{cm}^{2}$ (very soft - stiff clay with inferred CU varying from $20-80 \mathrm{KN} / \mathrm{m}^{2}$ ), and $14-58 \mathrm{~kg} / \mathrm{cm}^{2}$ (stiff clay - medium dense sandy silt), with sleeve friction values ranging from $5-19 \mathrm{~kg} / \mathrm{cm}^{2}, 12-89 \mathrm{~kg} / \mathrm{cm}^{2}$, and $76-201 \mathrm{~kg} / \mathrm{cm}^{2}$ respectively. The friction ratio obtained varies between $0.62-3.98$ (upper $3 \mathrm{~m}$ ), $1.1-5.69$ (3-10 m depth), and $1.88-5.68$ (10 - $20 \mathrm{~m}$ depth). The graph also depicts low resistance values from 4 to $10 \mathrm{~m}$ depth, after which it begins to increase. At CPT 10, the soil profile depicts four geologic sequence consisting of sandy silt to clayey 
silt/silty sand to sandy silt $(0-4.25 \mathrm{~m})$, clay/silty clay to clay $(4.25-17.5 \mathrm{~m})$, sandy silt to clayey silt $(17.5-18.5 \mathrm{~m})$ and clay $(18-20$ $\mathrm{m}$ ). The cone resistance, sleeve resistance and friction ratio ranges from $3-29 \mathrm{~kg} / \mathrm{cm}^{2}, 13-51 \mathrm{~kg} / \mathrm{cm}^{2}$, and $0.51-1.25$ at depth $0-3 \mathrm{~m}$; $2-25 \mathrm{~kg} / \mathrm{cm}^{2}, 19-82 \mathrm{~kg} / \mathrm{cm}^{2}$, and $1.1-5.69$ for depth between $3-10 \mathrm{~m} ; 21-91 \mathrm{~kg} / \mathrm{cm}^{2}, 89-223 \mathrm{~kg} / \mathrm{cm}^{2}$, and $1.88-5.68$. This CPT point is predominantly made of fines (clay and silt), although at depth of $0-4.25$ it's contains small amount of sand. This could the major reason why less settlement/subsidence occurred at this point location.

Subsequently, the failure at this segment could have been induced by incessant heavy flooding around the embankment/shoulder of the highway. This flood water has infiltrated the subgrade material leading to looseness, and less-cohesiveness of the layer. Erosion control is an integral part of highway drainage. Excessive erosion may plug culverts, leading to saturation of the pavement structure and failure of drainage systems, and finally resulting to pavement failure. Environmental considerations that dictate erosion must be controlled. Surface drainage must be provided to drain precipitation away from the pavement structure. In a simple example, cross slope directs water to the shoulder where it flows into a ditch, then down the ditch to a culvert and finally into an existing natural drainage. Therefore figures 8 and 9 shows the extents of weathering and erosion resulting in increase in porosity and compressibility of the subsoil (Graham and Shields, 1984). At both failed segments, the upper $6 \mathrm{~m}$ is seriously affected by this erosion. It's expected that the soil should treated with best stabilization method during rehabilitation/reconstruction of the failed portion of the highway.

\section{Conclusions}

Findings of the investigation revealed that failure at both segments of the studied highway is due to construction on geotechnical weak soil, with cone resistance values generally less than $20 \mathrm{~kg} / \mathrm{cm}^{2}$ with inferred unconfined compressive strength less than $75 \mathrm{KN} / \mathrm{m}^{2}$. The weakness of this soil layer revealed by incessant heavy flooding around the embankment/shoulder of the highway might have induced the failure since a bridge was supposed to have been constructed across the two failed segments. The flood water might have infiltrated the subgrade material leading to looseness, and less-cohesion of the layer every wet seasons. This consequently damages the road embankment and shoulders, thereby seeping into the clayey subsoil with intermediate plasticity. This phenomenon increases the clayey porosity and permeability resulting in poor geotechnical properties (A-7/A-7-6). It is therefore suggested that drainages / gutters should be provided along the shoulders of the highway to prevent erosion along shoulders and side slopes (Gidigazu, 1983). This is also an acceptable method of erosion control in areas without paved shoulders. In this case the curb should be placed along the edge of the pavement. Water should then be channeled to roadside drainage channels. Also bridge or culvert should be constructed across both failed segments to ease flow of water along the natural course of stream/water flow. Embankments should be constructed instead of using the natural in-situ soil material. Typical requirement for elevated embankment includes the use of good drainable material spread in thin lifts and compacted to the required density. Where good material sources are easily available, embankment materials falling between the classification of A-1-a and A-4 per AASHTO M145 are preferred. Materials meeting A-1-a classification would preferred around and behind structures, while A-4 material may be acceptable within the roadway prism but away from structures. Broken up pieces of concrete may be used within the embankment fill provided the largest dimension is no greater than $1 / 3$ of the fill height. Care should be taken to ensure that these large size materials do not nest to create large voids that could become detrimental to the performance of the embankment due to excessive settlement.

\section{Declarations}

\section{Acknowledgements}

Not applicable.

\section{Author's contribution}

Author 00 designed and carry out the fieldwork to acquire the data; analyzed the data and compiled the research work. The author also wrote, read and approved the final manuscript.

\section{Funding}

Funding of the entire work was personal.

\section{Availability of data and materials}

The data sets used and analyzed during the current study are available from the corresponding author on request. 


\section{Competing interest}

The author declares that no competing interests exist.

\section{Author details}

Author $\mathrm{OO}$ holds Bachelor of Science in Geology; Master of Technology in Exploration Geophysics; Master of Philosophy in Hydrogeology; and Doctor of Philosophy in Engineering Geology and Geotechnics. He is presently Lecturer in the Department of Civil Engineering Technology, Faculty of Engineering Technology, Rufus Giwa Polytechnic Owo Nigeria.

\section{References}

AASHTO (1993) Guide for design of pavement structures. American Association of State Highway and Transportation Officials, Washington, DC

Abynayaka SW (1977) Prediction of Road Construction Failure in Developing Countries. Proc. Institute of Civil Engineering Part I, Pp. 419446

Akintorinwa OJ, Adeusi FA (2009) Integration of Geophysical and Geotechnical Investigation for a Proposed Lecture Room Complex at the Federal University of Technology Akure, Southwestern Nigeria. Ozean J. Appl. Sci. 2(3):1943-2429.

Akpokodje EG (1986) The geotechnical properties of lateritic and non-lateritic soils of southeastern Nigeria and their evaluation for road construction. Bulletin of Engineering Geology and the Environment Volume 33, Number 1, pp.115-121.

(http://www.springerlink.com/content/a37771860k4n7k96/)

Akujieze CN (2004) Effect of Anthropogenic Activities on Urban Groundwater System and Aquifer Vulnerability Assessment in Benin City, Edo State Nigeria. Ph.D. Dissertation, University of Benin, Edo State, Nigeria.

Akujieze CN, Oteze GE (2006) Groundwater Quality of Benin City Urban Aquifer of the Pleistocene Oligocene Benin Formation Nigeria. Afr. Sci. 7(2):54-60.

Ayolabi EA, Folorunso AF, Jegede OE (2012) The Application of 2D Electrical Resistivity Tomography in Geotechnical Investigations of Foundation Defects, Ogudu Estate as a Case Study. Journal of Geology and Mining Research, 3(12): 142 - 151.

Bell FG, Cripps JC, Culshaw M (1990) Field testing methods for engineering geological investigations. IN Field Testing in Engineering Geology (ed. Bell et al), Geol. Soc. Eng Geol. Spec. Pub. No.6, 3-20.

Black W, Lister NW (1978) The strength of fill sub-grades, its prediction and relation to road performance.

ICE Conf. on Clay Fills. 37-48

Brown SF (1996) Soil mechanics in pavement engineering. Geotechnique, 46, 383-426.

BS 1377 (1990) Method of testing for soils for civil engineering. British Standard Institution, London

Cassagrande A (1947) Classification and identification of soils. Am Soc Civil Eng. 113:783-811

Cassagrande A (1972) Classification and Identification of Soil Transaction ASCE, Vol. 113 New Yolks.

Coerts AO (1996) Analysis of static cone penetration test data for subsurface modelling. A methodology - PhD Thesis, Nethernals Geographical Studies 210, 263pp

Coker JO, Makinde V, Adesodun JK, Mustapha AO (2013) Integration of Geophysical and Geotechnical Investigation for a Proposed New Lecture Theatre at Federal University of Agriculture, Abeokuta, South western Nigeria. International Journal of Emerging Trends in Engineering and Development Issue 3, Vol.5: 338-348

Coker JO (2015) Integration of Geophysical and Geotechnical Methods to Site Characterization for Construction Work at the School of Management Area, Lagos State Polytechnic, Ikorodu, Lagos, Nigeria. 
International Journal of Energy Science and Engineering, Vol. 1, No. 2, pp. 40-48.

Daramola SO, Malomo S, Asiwaju-Bello YA (2018) Premature failure of a major highway in Southwestern Nigeria: the case of Ipele-Isua. International Journal of Geo-engineering 2018: 9:28, 1-12pp. https://doi.org/10.1186/s40703-018-0096-9

Das BM (2000) Fundamentals of geotechnical engineering, $4^{\text {th }}$ Ed., USA.

Federal Ministry of Works and Housing (1997) Nigerian general specifications for roads and bridges. Federal Highway Department. $2: 145-284$

Gidigasu MD (1983) Development of acceptance specifications for Tropical Gravel paving materials. Engineering Geology.19, pp.213-240 Graham J, Shields DH (1984) Influence of geology and geological processes on the geotechnical properties of a plastic clay. Journal of Engineering Geology Volume 22, Issue 2, pp109-126. http://www.sciencedirect.com/science/journal/00137952

Hartley A (1974) A review of the geological factors influencing the mechanical properties of road surface aggregates. QJEG, 7, 69-100.

Ibe AC (1988) Coastline erosion in Nigeria. Ibadan university press, Ibadan, Nigeria.

Jegede G (1995) Soil Erosion by Water, its Effect on Highway Pavement Failures in South-western Nigeria. Proceeding UNESCOMAB Regional Training Workshop, FUTA. pp. 319-322.

Jegede G (1999) Engineering Geological Significance of the Superficial Deposits in Carrington Hill Area, Country Conc, Ireland. Nig. J. Sci. 28:153-158.

John H, Gorden H (1976) A practical Guide to Earth Road Construction and Maintenance, Engineering Manual Vol. 2, No. 1. Pp. 43-45.

Kadyali LR, Lal NB (2008) Highway Engineering. Khanna Publishers Delhi-6, Fifth Edition, 858pp.

Lunne T, Robertson PK, Powell JJM (1997) Cone Penetration Testing in Geotechnical Practice, Blackie Academic and Professional, London, $312 p$

Momoh LO, Akintorinwa O, Olorunfemi MO (2008) Geophysical Investigation of Highway Failure- A Case Study from the Basement Complex Terrain of Southwestern Nigeria. Journal of Applied Sciences Research. 4(6): 637-648.

NITRR (1987) The Design of Road Embankments: TRH 10. Tech. Recommendations for Highways, CSIR, Pretoria.

Nton ME (2001) Sedimentological and Geochemical Studies of Rock Units in the Eastern Dahomey Basin, South Western Nigeria. PhD thesis, University of Ibadan, 315pp.

Oglesby CH, Garry HR (1978) Highway Engineering, fourth edition, John Willey and sons, New York, p.691.

Olorode DO, Adedayo AS, Akintunde AO (2016) Application of Geotechnical And Geophysical Methods To Investigate Tilt Buildings At Lagos State, Nigeria. IOSR Journal of Applied Geology and Geophysics (IOSR-JAGG), Volume 4, Issue 5 Ver. II, pp. 21-28. DOI: $10.9790 / 0990-0405022128$

Omatsola ME, Adegoke OS (1981) Tectonic Evolution and Cretaceous Stratigraphy of the Dahomey Basin. Journal of Mining and Geology, 8: 30-137.

Oyedele KF, Okoh C (2011) Subsoil investigation using integrated methods at Lagos, Nigeria. Journal of Geology and Mining research, Vol. 3(7), pp. 169-179.

Oyedele KF, Olorode DO (2010) On Site Investigation of Subsurface Conditions using Electrical Resistivity Method and Cone Penetration Test at 'Medina Brook Estate, Gbagada, Lagos, Nigeria. World Applied Science Journal, 11 (9): 1097-1104.

Ozegin KO, Oseghale A, Okolie EC, Ujuanbi O (2011) Integration of very low-frequency electromagnetic (VLF-EM) and electrical resistivity methods in mapping subsurface geologic structures favourable to road Failures. International Journal of Water Resources and Environmental Engineering Vol. 3(6), pp. 126-131.

Paul HN, Radnor JP (1976) Highway Engineering, John Willey and Sons, New York. 
World Bank (1991) Nigeria Highway Sector Study Journal, Vol. II, No.2

Robertson PK (1990) Soil classification using the cone penetration test. Can Geotech J 27:151-158.

Sandy MJ, Cole WF (1982) The influence of the degree of weathering of hornfels rock on its physical properties and durability. Proc. 11th ARRB Conf. Part 3, 80-89

Saunders MK, Fookes PG (1970) A review of the relationship of rock weathering and its significance to foundation engineering. Eng. Geol. 4, 289-325

US Army Corps of Engineers (2004) General Design and Construction Considerations for Earth and Rock Fill Dams Handbook Manual. Washington, DC 20314-1000, 130pp.

\section{Figures}

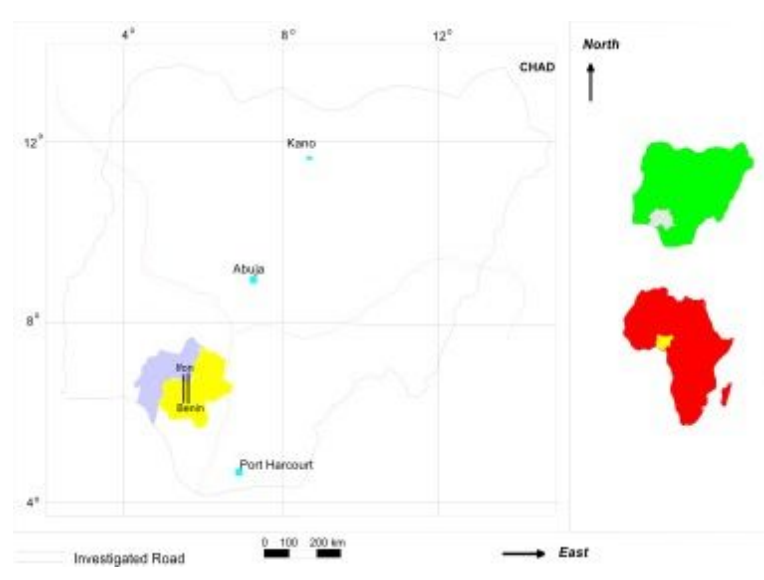

\section{Figure 1}

Map showing the Location of the Study Area on Nigeria and Africa maps
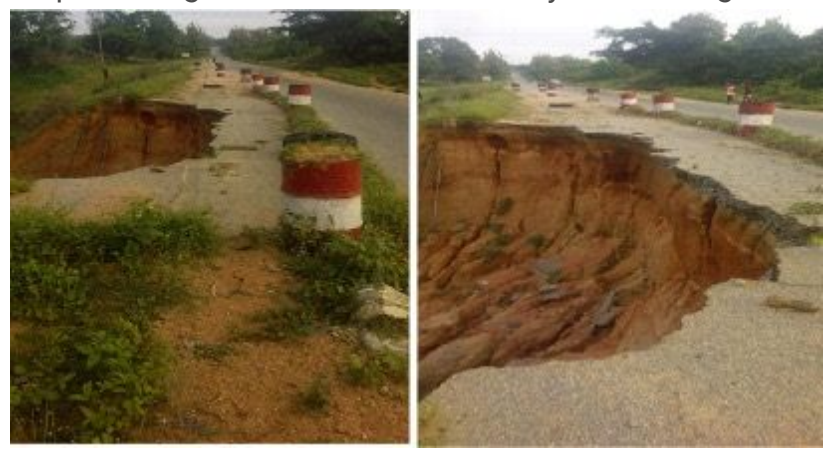

\section{Figure 2}

Photographs showing failed segment 1 at Ifon in Ondo State (a) collapse pavement structure (b) eroded foundation soil and destroyed buried cables and utilities by erosion

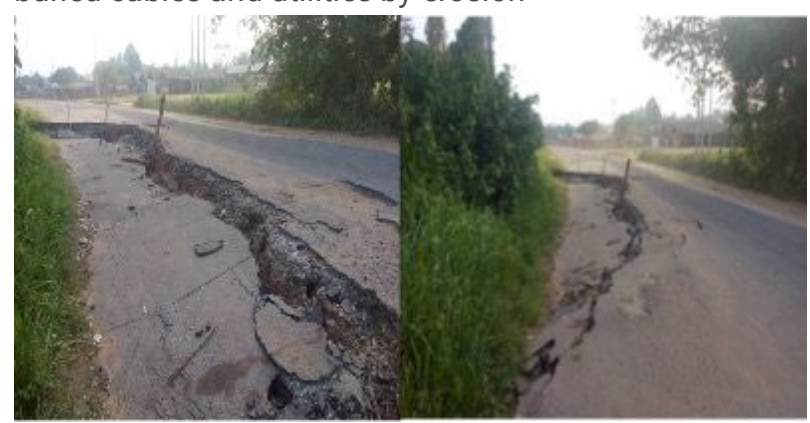




\section{Figure 3}

Photographs of the collapsed/subsided pavement structure along Owan - Uyere Highway, representing failed segment 2 North.

cor 1 ported stith segrenc) $\rightarrow$ South

If $6 \mathrm{n}+0.0 \mathrm{Km}$

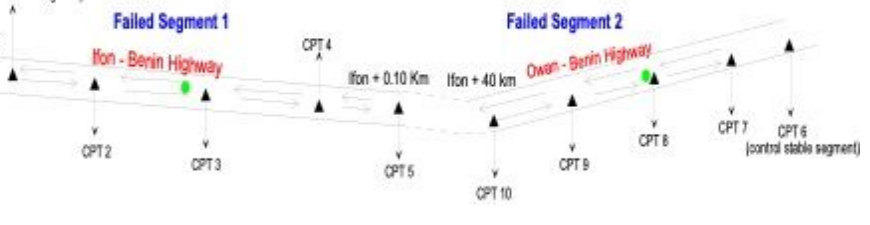

Highway \ CPT Point * Sample Colloction Poim

\section{Figure 4}

Sketch of the field layout of the CPT Points and trial pit sampling points along investigated failed segments of the Highway
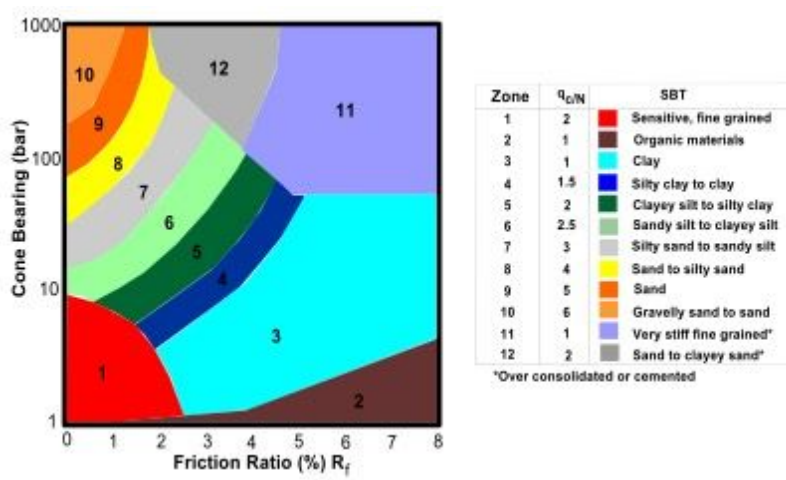

\section{Figure 5}

Robertson Chart for Soil Classification using cone resistance value and friction ratio (Robertson 1990) 


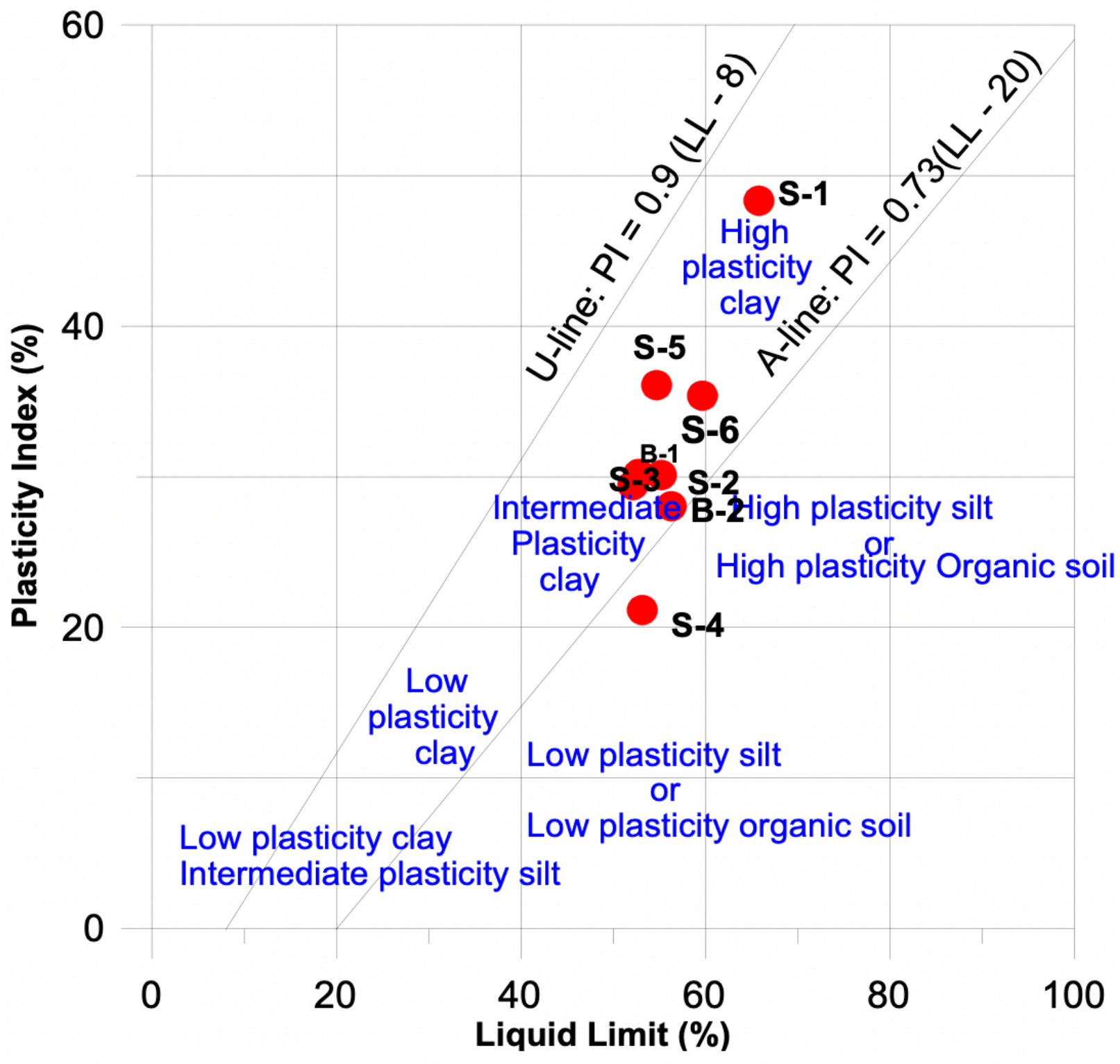

Figure 6

Casangrande Plasticity Chart for the Studied Soil Samples showing predominant intermediate plasticity clay Granulary Masterials
(35\% or kess passing No. 200) Silh-Cley Materials
(Mare $35 \%$ or less pasing Na. 200)

Gencral Clessflataina

Geop Clasifienoen

Sive antysis, perceatage pasing

No. $10(200 \mathrm{~mm})$

No. $40(9425 \mathrm{~mm})$

No $26000075 \mathrm{~mm}$

Cheraterisices of fracting prome

$\left.\mathrm{Na}_{\mathrm{s}} 40,0.25 \mathrm{~mm}\right)$

Lipis Limit

Fasiacty tinder

Usul topes of sigrifient

Genenl Rsing as styath

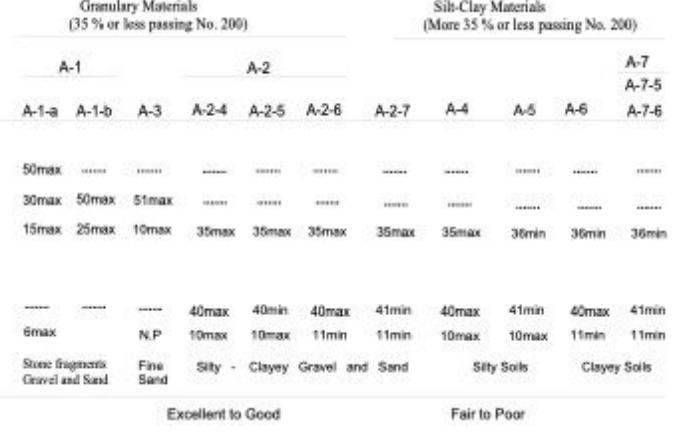

Figure 7

AASHTO Soil Classification System for Civil Engineering Highway Construction 


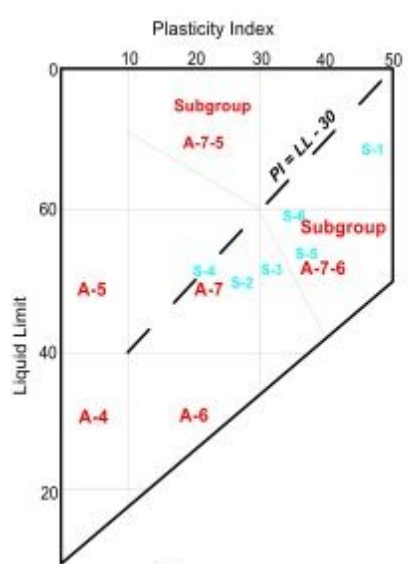

(a)

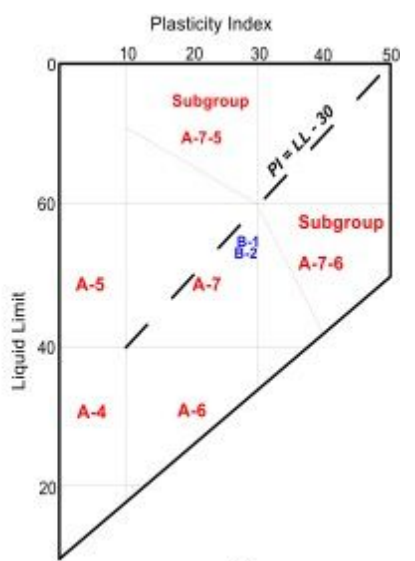

(b)

\section{Figure 8}

AASHTO soil classification Chart for A-7 Subgroup for study sites

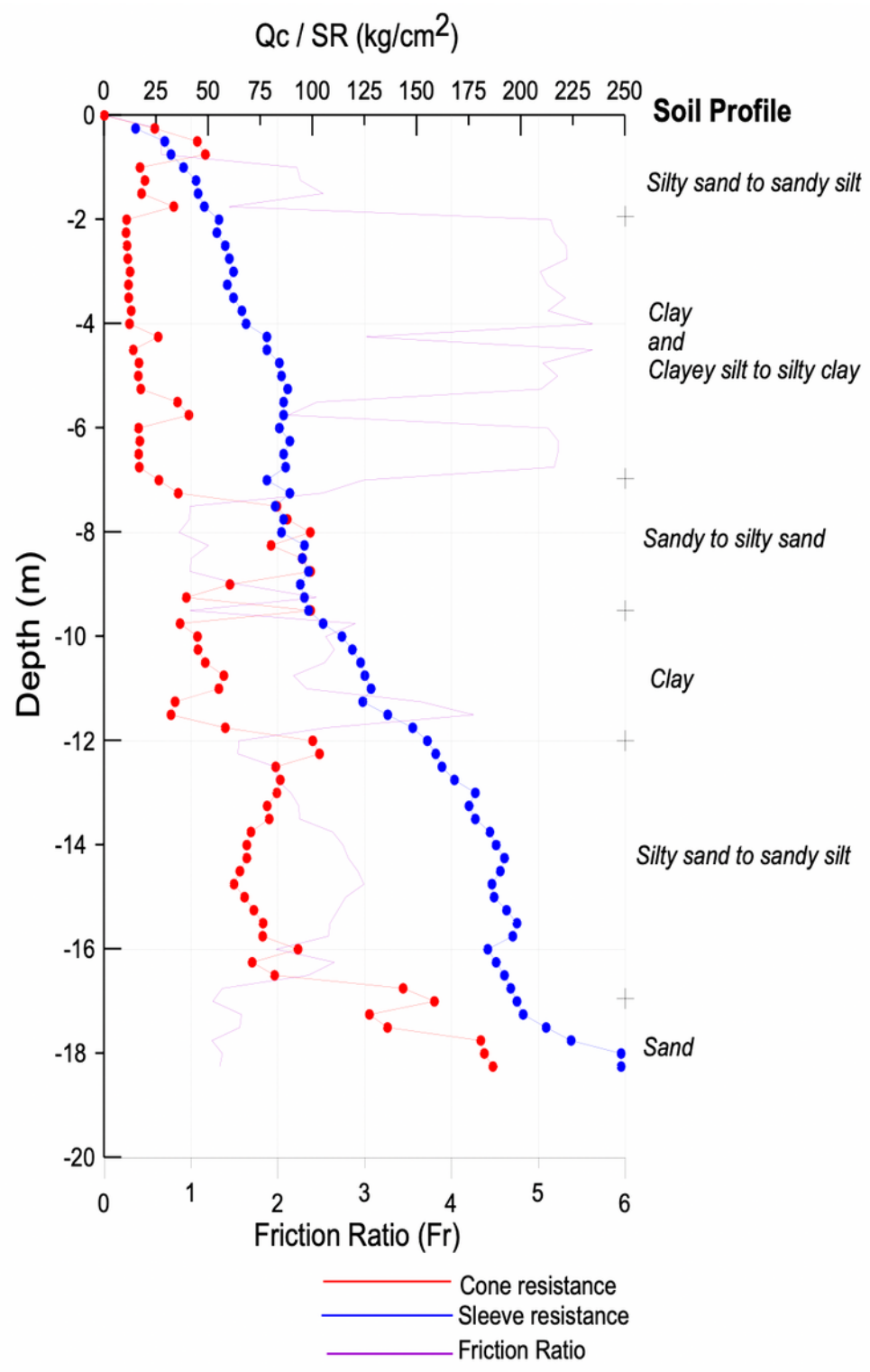

\section{Figure 9}

Plots of Cone resistance, Sleeve resistance, and friction ratio against depth at the stable segment of location 1 


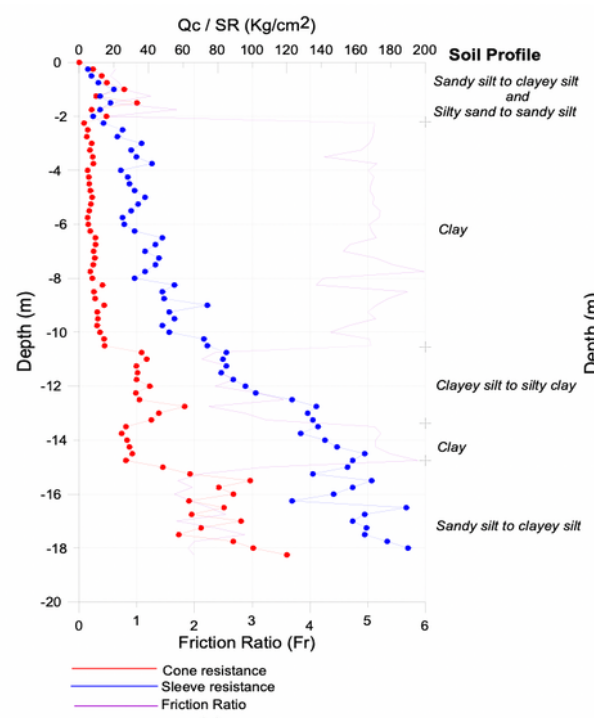

(a)

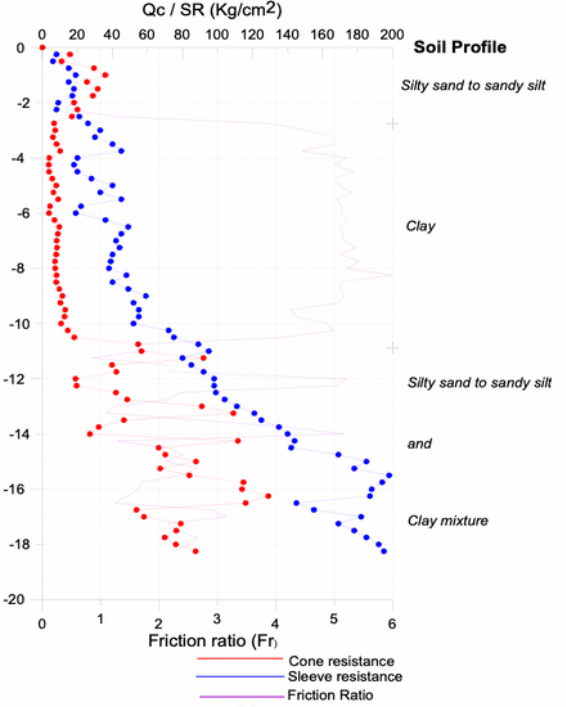

(b)

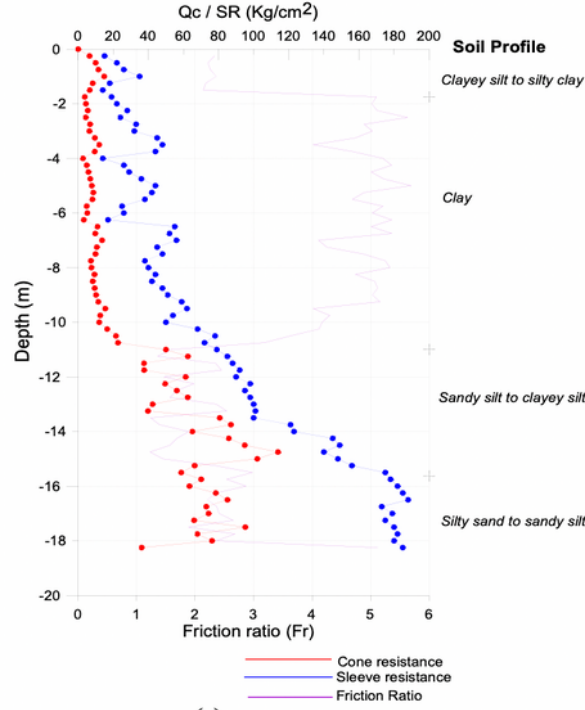

(c)

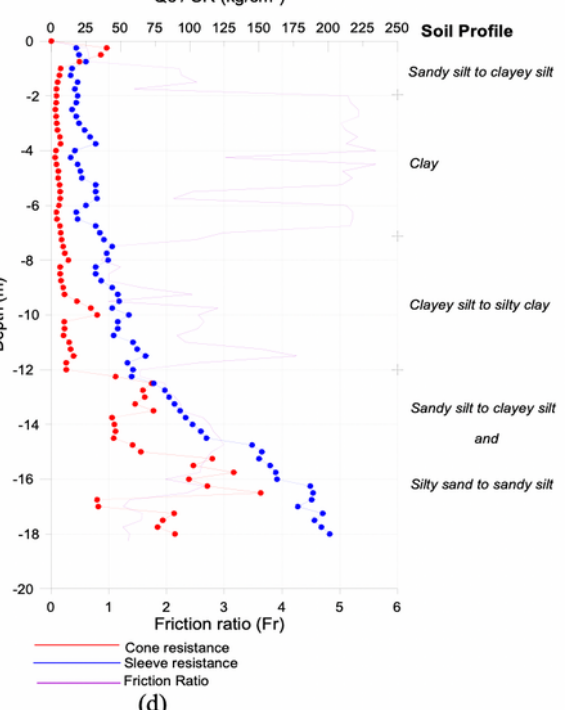

(d)

\section{Figure 10}

The Plots of CPT Values against Depth and their corresponding interpreted geologic sections along failed segment 1 (a) CPT 2 (b) CPT 3 (c) CPT 4, and (d) CPT 5 


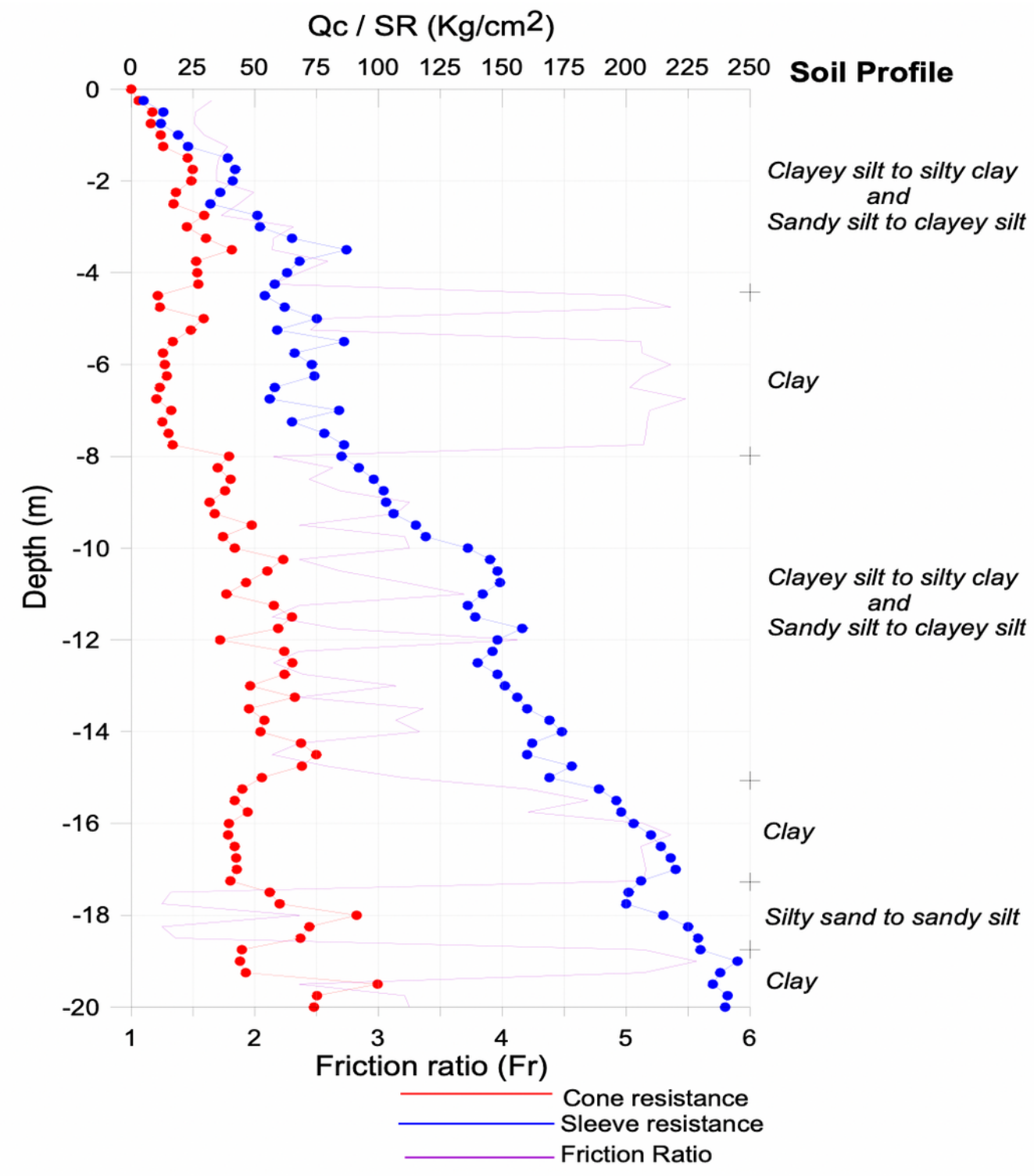

Figure 11

Plots of Cone resistance, Sleeve resistance, and friction ratio against depth at the stable segment of location 2 

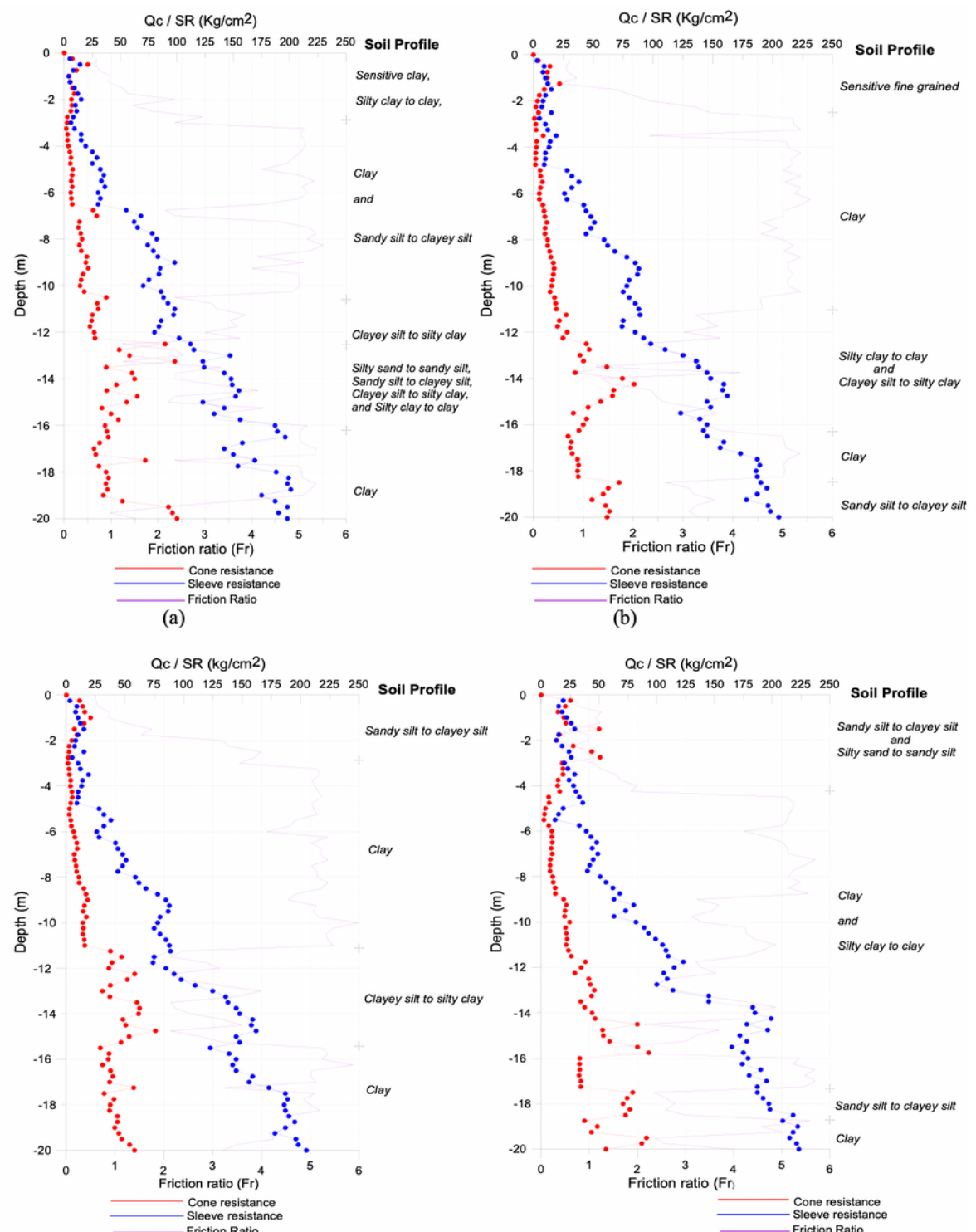

(c)

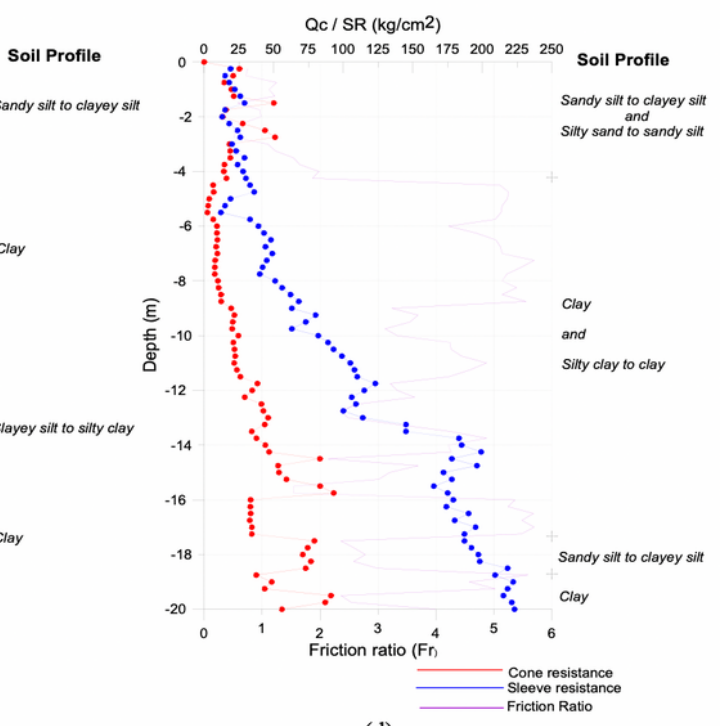

(d)

\section{Figure 12}

The Plots of CPT Values against Depth and their corresponding interpreted geologic sections along failed segment 2 (a) CPT 6 \& 7 (b) CPT 8 \& 9 (c) CPT 10 


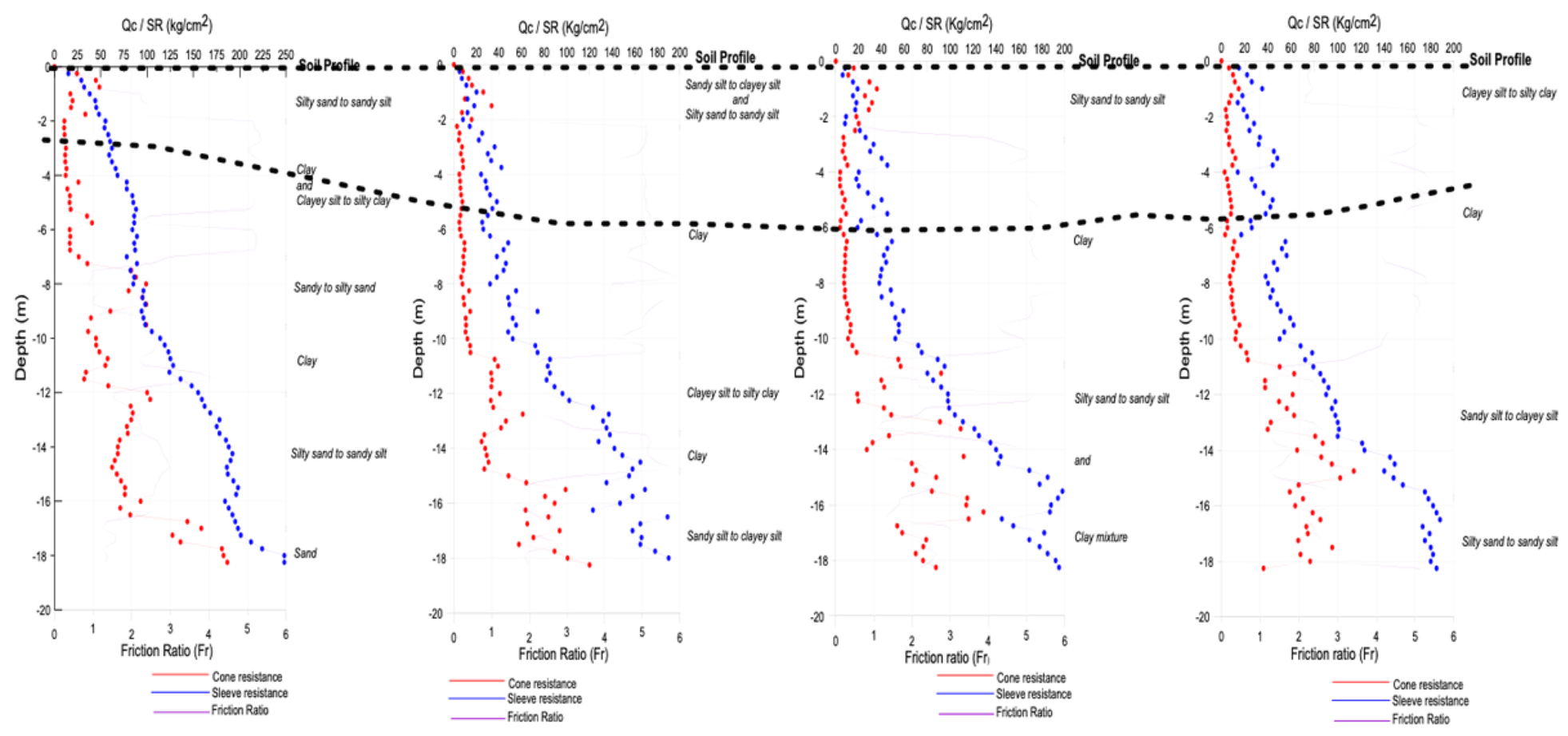

Znes seriously affected by erosion and weathering

Figure 13

The plots of cone resistance, sleeve resistance, and friction ratio across the failed segment 1, showing upper $2.5 \mathrm{~m}$ (CPT 2 ) - 6 m which have been seriously affected by erosion and weathering.

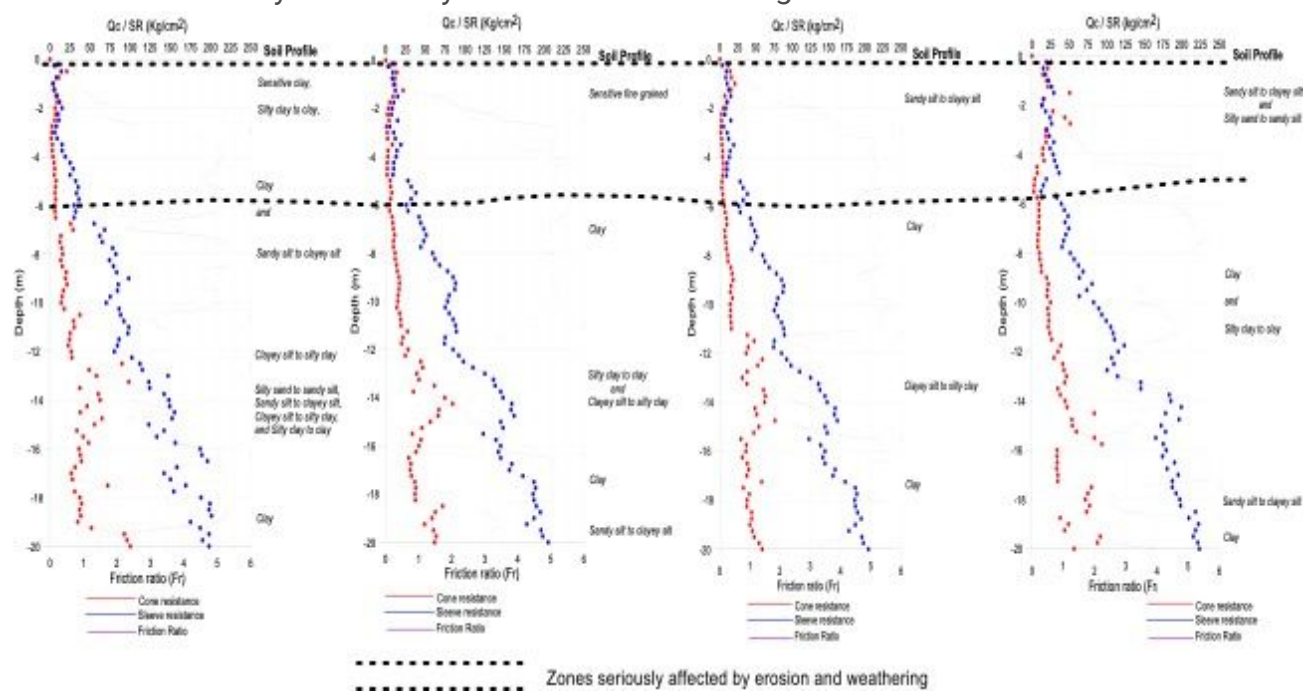

Figure 14

The plots of cone resistance, sleeve resistance, and friction ratio across the failed segment 2, with the upper $6 \mathrm{~m}$ seriously affected by erosion and weathering leading high compressibility and settlement under traffic load 